\title{
Müze Ziyaretinin Öğretmen Adaylarının Düşüncelerine Etkisinin İncelenmesi
}

\author{
Yrd. Doç. Dr. Canan LAÇİN ŞİMŞEK* \\ Sakarya Üniversitesi, Eğitim Fakültesi, İlköğretim Bölümü Fen Bilgisi Öğretmenliği ABD, \\ Hendek, Sakarya
}

\section{Yrd. Doç. Dr. Fatime BALKAN KIYICI}

Sakarya Üniversitesi, Eğitim Fakültesi, İlköğretim Bölümü Fen Bilgisi Öğretmenliği ABD, Hendek, Sakarya

\section{Yrd. Doç. Dr. Elif ATABEK YİĞİT}

Sakarya Üniversitesi, Eğitim Fakültesi, İlköğretim Bölümü, Fen Bilgisi Öğretmenliği ABD, Hendek, Sakarya

\section{Özet}

Bu çalışmada, İlköğretim Fen Bilgisi Öğretmenliği Programı 3. sınıf dersi olan Bilimin Doğası ve Bilim Tarihi dersini alan öğretmen adaylarının, bu derste öğrendikleri bilgilerden sonra gerçekleştirilen bir müze ziyaretinin, Türk-İslâm bilginleri ve bilime katkıları ile ilgili düşüncelerine etkisi incelenmiştir. Bu amaçla 25 öğretmen adayından oluşan çalışma grubuyla beraber İslâm Bilim ve Teknoloji Tarihi Müzesine bir gezi düzenlenmiştir. Çalışmanın verileri gezi öncesi ve sonrasında açık uçlu

* Sorumlu Yazar. Tel: +90 2646141033 E-posta: csimsek@sakarya.edu.tr 
soruların yer aldığı bir form aracılığı ile formu gönüllü olarak doldurmak isteyen öğretmen adaylarından elde edilmiştir. Veriler, içerik analizi ile değerlendirilmiştir. Çalışma sonucunda öğretmen adaylarının fikirlerine dayanarak müze ziyaretlerinin, öğrenilen bilgilerin pekişmesini, daha anlamlı hale gelmesini sağladığını, düşüncelerin değişiminde olumlu etkileri olduğunu ve ayrıca ziyaretin duyuşsal alana yönelik birtakım farklılıklar da yarattığını söylemek mümkündür.

Anahtar Kelimeler: Müze ziyareti; Türk-İslâm bilginleri; Bilimin doğası ve bilim tarihi; Okul dışı öğrenme; İnformal öğrenme.

\title{
Investigation of the Effect of Museum Visits on Teacher Canditates' Thoughts
}

\begin{abstract}
In this study, effect of a museum visit which was done after having been thought about some scientists in the history Nature and Science History course on teacher candidates' thoughts regerding Turkish-Islamic scientists and their contributions to science were investigated. By this aim, a field visit to Museum for the History of Science and Technology in Islam was arranged with 25 teacher candidates. Data of the study were obtained by a form where open ended questions were asked and the form was filled by teacher candidates. Data were analyzed by content analysis. According to the findings of the study, it can be concluded that museum visits can help to stiffen the learned knowlegde, to make them more meaningful and also have positive effects on change of thoughts. Besides, visits can also make differences in affective area.
\end{abstract}

Keywords: Museum trip; Turkish-Islamic scientist; The nature of science and science history; Out of school learning; Informal learning.

\section{Extended Summary}

\section{Purpose}

The aim of this study is to investigate the effect of a museum visit on teacher candidates' ideas about Turkish-Islamic scientists and their 
contributions to the development of science. First teacher candidates have been given the course of the Nature of Science and Science History, then a field visit was done to the museum for the History of Science and Technology in Islam after they have been taught about Turkish-Islamic scientists in the said course. In this context, answers to following questions were investigated:

a) What were the teacher candidates' ideas about Turkish-Islamic scientists and their contributions to science before the trip?

b) How did this museum visit effect the teacher candidates' ideas about their contributions to science?

c) How did the museum visit effect the teacher candidates' thoughts about Turkish-Islamic scientists?

d) How realistic were the teacher candidates perceptions regarding Turkish-Islamic scientists contributions to science before the visit?

e) How did the museum visit effect the teacher candidates' realistic perception on their contributions to science?

\section{Method}

A field visit to Museum for the History of Science and Technology in Islam was arranged with 25 teacher candidates. Data of the study were obtained by a form in which open ended questions were asked and the form were filled voluntarily by teacher candidates. Data were analyzed by content analysis. 


\section{Results}

Findings of the study are as follows:

Before the museum visit all teacher candidates have concluded that Turkish-Islamic scientists had important contributions to science. Besides, some teacher candidates have mentioned the effect of the course and said that they have realized the important contributions of these scientists by the course. Some teacher candidates said that they have never been heard about these scientists’ names before. Also, some teacher candidates have added that these scientists pioneered to the science.

According to the teacher candidates' views, the museum visit made an effect on their toughts about the contributions of Turkish-Islamic scientists to science as affectively and cognitively. Teacher candidates' responses such as increase of confidence/belief, being convinced, proud of, appreciation/appraisal, increase of curiosity/desire of investigation, sadness because of absence of appreciation/being unaware of them were grouped as affective expressions. Embodiment of abstraction for the knowledge about them and increase in awareness level were thought as cognitive expressions.

Before the museum visit the teacher candidates' expressions about the realistic perceptions related to Turkish-Islamic scientists' contributions to science were collected in three groups as "feeling a realistic perception, feeling a fully realistic perception and having no realistic perception”. 
After the visit some teacher candidates have said that their realistic perceptions about the scientists were changed while some others said that no change were occured since they already had such a realistic perception about their contributions to science.

\section{Discussion}

The predominant approach in History of Science is that science has jumped with Renaissance and its fundementals have been going to ancient Greeks (Hobson, 2008). By the effect of this point of view, generally western scientists' contributions and their discoveries and inventions have been presented in the courses. Therefore teacher candidates have been only aware of the contributions of western scientists. In this context, a field visit was arranged for teacher candidates in order to understand the effect of such a visit to their thoughts about Turkish-Islamic scientists. Before the visit some teacher candidates have responded that they have never been heard anything about Turkish-Islamic scientists' names and some of them have also said that they have been aware of these scientists' contributions by the effect of the course. Therefore it can be said this is a result and demonstration of western approach on history of science (Göker, 1998; Sezgin, 2007) in our education system.

After the museum visit, teacher candidates' responses on the contribution of Turkish-Islamic scientists to science could be categorized into two groups as affective and cognitive. Therefore it can be said that this museum visit have affected teacher candidates' thoughts affectively as they have stated that their knowledge became more 
concrete, a more meaningfull understanding have been occured in their minds and they have been realized that Turkish-Islamic scientists have had contributions on science. Also, teacher candidates' expressions like "proud of, be convinced, increase in value" have shown the cognitive part of the effect. Therefore the museum visit effected teacher candidates' thoughts with their affective structures as well as their cognitive structures.

\section{Conclusion}

A field visit to the museum was arranged in regard to the History of Nature and Science History course with its chapter of Turkish-Islamic Scientists. After the visit, teacher candidates expressed that they stiffened their learnings, became more meaningful, were convinced about Turkish-Islamic scientists' contributions to science after seeing the models of the instruments that these scientists had been developed. Besides, some teacher candidates have said that their realistic perceptions were increased after the visit and some other have said that they were proud of them. Even teacher candidates who expressed no realistic perception about the contributions of Turkish-Islamic scientists by the effect of courses in which western science and scientists have been handled, said that their feelings and thoughts have been changed and they have been convinced after this visit. In the light of the data, it can be said that museum visit can have positive effects in stiffening of learned knowledge, in having more meaningful learning and in having positive effects on change in some thoughts. Besides, these visit can contribute to cognitive structures. 


\section{Giriş}

Eğitim alanında yapılan reformlarla birlikte, kullanılan yöntem ve teknikler zenginleşmiş ve çeşitlenmiş, bu yöntem ve tekniklerle birlikte amaç sadece bilgi iletimi olmaktan çıkmış, duyuşsal ve psikomotor alanlarda da değişimlerin desteklenmesi hedeflenmiştir. $\mathrm{Bu}-$ nunla birlikte, eğitim etkinliklerinin yapıldığı yerlerin sadece sınıf ortamları olabileceği düşüncesi de değişmiş, okul dişında yer alan ortamların da, eğitim etkinliği için kullanılabileceği fikri doğmuştur. Dolayısıyla, müzeler, hayvanat bahçeleri, botanik bahçeleri, akvaryumlar vb. alanlar eğitim ortamları olarak değerlendirilmeye başlanmiştır.

Müzeler, hayvanat bahçeleri, botanik bahçeleri, akvaryumlar, planetaryumlar vb. ortamlarda gerçekleşen öğrenmeler, yaygın olarak okul dışı öğrenme (informal öğrenme) olarak kavramsallaştırılmaktadır. Okul dişı öğrenme, bireyin ilgi ve ihtiyaçları doğrultusunda yönlendirilen, serbest seçimli, sıralı olmayan, kendi hızında ilerleyen ve gönüllü olan öğrenmeler olarak tanımlanmaktadır (Falk ve Dierking, 2002; Rennie, Feher, Dierking ve Falk, 2003). Fen öğretiminde okul dışı ortamlar sıklıkla başvurulan yerler hâline gelmiştir. Çünkü öğrencilerin okulda öğrendiklerinin okul dışında pekiştirilerek onların günlük hayatla ilişki kurmalarının sağlanmasının önemli ve gerekli olduğu düşünülmektedir. Okul dışı fen öğretiminde amaç, öğrenme ortamının değiştirilmesini desteklemek, fene yönelik ilgiyi artırmak ve öğrencilerin fen başarısını yükseltmektir (Dori ve Tal, 2000).

Okul dışı öğrenme ortamı olarak en sık kullanılan yerlerden olan 
müzeler, okuldaki eğitimi zenginleştirici, destekleyici ve tamamlayıcı bir potansiyele sahiptir (Baykan, 2007). Müze eğitimi zihinsel kavrayış yanında empatik bağlar kurmayı, merak etmeyi, eleştirel bakmayı ve pratik beceriler kazanmayı da sağlayabilmektedir (Seidel ve Hudson, 1999). Yapılan araştırmalarda, müzelere yapılan esnek ve yaratıcı gezilerin fen derslerinde öğrenilen konuları tamamladığı görülmektedir. $\mathrm{Bu}$ ortamların, öğrencilerin fen becerilerinin gelişmesinde, çeşitli bilimsel konuları keşfederek öğrenmelerinde, akademik başarılarının ve fene karşı tutumlarının artmasında ve bilimsel meraklarının canlanmasında etkili olduğu ve öğrenmeyi kolaylaştırdığı, birinci elden deneyim kazanılmasına fırsat verdiği, gerçek hayat ile okulda öğrendikleri arasında ilişki kurma, gözlem yapma, veri toplama ve sonuca ulaşarak yorum yapma becerilerinin gelişmesine katkıda bulunduğu tespit edilmiştir (Balkan Kıyıcı ve Atabek Yiğit, 2010; Bozdoğan, 2007; Chin, 2004; Cox-Petersen, 1999; Griffin, 2004; Guisasola, Morentin ve Zuza, 2005). Bunun yanında, öğrencilerin bu mekânlarda sözlü iletişim uygulamaları yaparak sosyal becerilerini de geliştirdikleri görülmüştür (Panizzon ve Gordon; 2003). Ayrıca, öğrencilerin, ziyaretler esnasında yaşadıkları deneyimleri daha uzun süre hatırladıkları belirtilmektedir (Anderson, Kisiel ve Storksdieck, 2006; Falk ve Dierking, 1997).

Ülkemizde de çok sayıda ve çeşitli alanlarda müzeler bulunmaktadır. Son yıllarda müze ile eğitim kavramı üzerinde durulan bir yaklaşım haline gelmiştir. Bu çalışmada da bir müze ziyaretinin öğretmen adaylarının belli bir konuda düşüncelerine etkisinin tespit edilmesi planlanmıştır. Müze olarak “İslâm Bilim ve Teknoloji Tarihi 
Müzesi” seçilmiştir. Bu müzenin seçilmesinin nedeni, müze ziyaretinin Bilimin Doğası ve Bilim Tarihi dersi kapsamında yapılmasıdır. Bilim tarihi, son y1llarda önemi fark edilen ve üzerinde s1klıkla durulan konulardan biri haline gelmiştir. Bilim tarihi konuları içerisinde, Türk-İslâm bilginlerinin katkılarına da değinilmektedir. Ancak, kendi kültürümüze ait olmasına rağmen Türk-İslâm bilginlerinin katkıları öğretmen adayları tarafından pek bilinmemektedir (Laçin Şimşek, 2011). Ders kapsamında bu katkıları öğrenen öğretmen adaylarının düşüncelerine bir müze ziyaretinin yapacağı katkının, bu çalışma ile ortaya konması amaçlanmıştır.

\section{Çalışmanın Amacı}

$\mathrm{Bu}$ çalışmanın amacı, İlköğretim Fen Bilgisi Öğretmenliği Programı 3. sınıf dersi olan Bilimin Doğası ve Bilim Tarihi dersini alan öğretmen adaylarının, bu derste öğrendikleri bilgilerden sonra İslâm Bilim ve Teknoloji Tarihi Müzesine yaptıkları ziyaretin, Türk-İslâm bilginleri ve bilime olan katkıları ile ilgili düşüncelerine etkisini incelemektir. Bu çerçevede şu sorulara cevap aranmıştır:

a) Müze ziyareti öncesi, öğretmen adayları Türk-İslâm bilginlerinin bilime katkıları ile ilgili neler düşünmektedirler?

b) Müze ziyareti, öğretmen adaylarının Türk-İslâm bilginlerinin bilime katkıları ile ilgili düşüncelerini nasıl etkilemiştir?

c) Müze ziyareti öğretmen adaylarının Türk-İslâm bilginleri ile ilgili düşüncelerini nasıl etkilemiştir?

d) Müze ziyareti öncesi, Türk-İslâm bilginlerinin bilime katkıları öğretmen adaylarına ne kadar gerçekçi gelmektedir? 
e) Müze ziyareti, öğretmen adaylarının Türk-İslâm bilginlerinin bilime katkıları ile ilgili gerçeklik algılarını nasıl etkilemiştir?

\section{Yöntem}

Çalışma, öğretmen adaylarının düşüncelerini belirlenmeye yönelik, açık uçlu sorularla verilerin elde edildiği nitel bir araştırmadır. Öğretmen adaylarının düşünceleri, açık uçlu sorularla toplanmıştır. Katılımcıların serbestçe cevap vermeleri istendiğinden açık uçlu sorulardan oluşan formun kullanılması tercih edilmiştir. Bu tür soruların avantajı, araştırmacının beklemediği veya planlamadığı cevapları da alabilmesi ve böylece konu hakkında daha geniş ve ayrıntılı bilgiye sahip olunabilmesidir (Büyüköztürk ve diğg., 2008).

Çalışma verilerini toplamak için araştırmacılar tarafından hazırlanan, açık uçlu sorulardan oluşan form geziye katılan ve formu gönüllü olarak doldurmak isteyen öğretmen adaylarına uygulanmıştır.

\section{Çalışma Grubu}

Çalışma grubunda, 2009-2010 eğitim öğretim yılında İlköğretim Bölümü Fen Bilgisi Öğretmenliği Programında öğrenim gören, Bilimin Doğası ve Bilim Tarihi dersini alan ve araştırmacılar tarafindan düzenlenmiş olan müze gezisine katılan ve ziyaret öncesi formu dolduran 22 öğretmen adayı (17 kız, 5 erkek) ve ziyaret sonrasında formu dolduran 25 öğretmen adayı (17 kız ve 8 erkek) yer almıştır.

\section{Süreç}

Araştırma sürecinde, Bilimin Doğası ve Bilim Tarihi dersi kapsamında bilim tarihi ile ilgili konularda, çeşitli uygarlık ve kültürlerin 
bilime katkılarından bahsedilmiştir. Daha sonra İslâm medeniyetinin bilim dünyasına katkıları ile ilgili öğretmen adaylarına bilgiler verilmiş, bu katkılarda payı olan bilginler tanıtılmıştır. Müzeye gidilmeden önce müze hakkında da bilgi verilmiştir. Çünkü, yapılan çalışmalarda, ziyaretçilerin ön bilgilerinin ziyaretin kalitesini etkilediği tespit edilmiştir (Anderson, Lucas, Ginns ve Dierking, 2000; Falk ve Adelman, 2003; Falk ve Storksdieck, 2005; Ramey-Gassert 1997). Gerekli bilgiler sunulduktan sonra, İslâm Bilim ve Teknoloji Tarihi Müzesi, geziye katılmak isteyen öğretmen adaylarıyla birlikte ziyaret edilmiştir. Ziyaretin başlangıcında, öğretmen adaylarına Türk-İslâm bilginlerinin katkıları ile ilgili bilgiler tekrar verilmiş, ziyaret esnasında hakkında bilgiler edinilmiş olan bilginlerin eserlerine dikkat çekilmiştir. Öğretmen adaylarının kendi ilgileri doğrultusunda müzeyi gezmelerine de firsat verilmiştir.

\section{Verilerin Toplanması}

Veriler açık uçlu sorulardan oluşan bir form ile elde edilmiştir. Ziyaret öncesinde araştırmacılar müze ziyaretinin amacı doğrultusunda 2 açık uçlu soru hazırlamışlardır. Formda yer alan sorular şu şekildedir:

1. Türk-İslâm bilginlerinin bilime katkıları ile ilgili neler düşünüyorsun?

2. Türk-İslâm bilginlerinin katkılarını düşündüğünde Batılı bilim insanlarının katkılarını düşündüğündeki gibi bir gerçeklik duygusu yaşıyor musun? Açıklar mısın?

Müze ziyareti sonrasında, öğretmen adaylarına yine 3 açık uçlu 
soru sorulmuştur. Bu sorular şu şekildedir:

1. Müzede gördükleriniz sizi nasıl etkiledi?

2. Müzede gördükleriniz Türk-İslâm bilginlerinin bilime katkıları ile ilgili düşüncelerinizi etkiledi mi?

3. Müzede gördüğünüz araç gereçler Türk-İslâm bilginlerinin katkılarıyla ilgili gerçeklik algınızda fark yarattı mı?

\section{Verilerin Yorumlanması}

Açık uçlu sorular aracılığıyla toplanan veriler, içerik analizi ile değerlendirilmiştir. Kodlamalar, 3 ayrı araştırmacı tarafından yapılmıştır. Öncelikle, araştırmacılar bağımsız olarak öğretmen adaylarının ifadelerini incelemiş ve kodlamışlardır. Daha sonra, bir araya gelerek, kodlamaları karşılaştırmış, fikir birliği olan kodlar alınmış, fikir ayrılığı olan kodlamalar tartışıldıktan sonra ortak bir karara varılmıştır. Daha sonra, bu kodları temsil eden temalar oluşturulmuştur. Bulgular kısmında, temalar, öğretmen adaylarının ifadeleri ile desteklenerek verilmiştir.

\section{Bulgular}

Açık uçlu sorular aracılığıyla toplanan veriler cevap aranan sorular doğrultusunda aşağıda sunulmuştur.

a) Müze ziyareti öncesi, öğretmen adayları Türk-İslâm bilginlerinin katkıları ile ilgili neler düşünmektedirler?

Geziye katılan bütün öğretmen adayları, Türk-İslâm bilginlerinin bilime önemli katkılar sağladığını ifade etmiştir. Bunun yanında bazı 
öğretmen adayları (4 öğretmen adayı) Bilimin Doğası ve Bilim Tarihi dersinin etkisine değinerek, Türk-İslâm bilginlerinin önemli katkılarını bu şekilde fark ettiklerini ifade etmişlerdir. Bunlardan 19 numaralı öğretmen aday1: “Bilim tarihi dersi almadan önce bu bilginlerin bilime katkılarının az olduğunu ya da hiç olmadığını düşünüyordum, bunun için bir araştırma yapmamıştım. Şimdi ise Türk-İslâm bilginlerinin katkılarının çok fazla ve önemli olduğunu gördüm." demiştir.

Ayrıca bazı öğretmen adayları (2 öğretmen adayı) bu bilim insanlarının isimlerini dersten önce hiç duymadıklarını dile getirmişlerdir. Örneğin, 9 numaralı öğretmen adayı, “Türk-İslâm bilginleri birçok bilimin gelişmesine katkıda bulunmuştur. Astronomi, fizik, matematik, kimya, biyoloji, felsefe gibi birçok alanda çalışmışlardır. Genellikle hepimiz Batılı bilim insanlarını tanımaktayız. Kendi bilim adamlarımızı tanımıyoruz, bunun çok büyük bir eksiklik olduğunu düşünüyorum. Ben de bugüne kadar bilmiyordum." demiştir.

Geziye katılan öğretmen adaylarından 8'i ise Türk-İslâm bilginlerinin önemli katkıları olduğu görüşüne ilaveten bilime öncülük ettiklerini/temel oluşturduklarını da belirtmişlerdir. Bununla ilgili olarak, 1 numaralı öğretmen adayı, "O dönem Ortaçağ Avrupası karanlık çağını yaşıyordu. Avrupa da ilerlemesi duran bilimi, Türk-İslâm bilginleri kendi dillerine çevirip yorumlamışlar ve daha ileriye gitmesini sağlamışlar. Bu sayede modern bilimin temellerini atmışlar. Birçok alanda Avrupa'da ve dünyada ilkleri yapmışlar. Bu şekilde bilime ve insanlı̆̆a büyük katkılar să̆lamışlar.” demiştir. 15 numaralı öğretmen adayı ise “Türk-İslâm bilginleri modern bilimin öncülüğünü yapmıştır 
ve her alanda katkılar sağlamışlardır. Kendi çağlarına göre bilim ve dinin yerini bilmişler ve dinî dogmalarının bilimsel çalışmalarına engel olmasına izin vermemişlerdir." demiştir.

\section{b) Müze ziyareti, öğrencilerin Türk-İslâm bilginlerinin katkl-}

\section{ları ile ilgili düşüncelerini nasıl etkilemiştir?}

Öğretmen adaylarının bu soruya verdikleri cevaplar duyuşsal ve bilişsel alana ilişkin olmak üzere iki tema altında toplanmıştır.

Duyuşsal alana ilişkin olarak öğretmen adaylarının ifadeleri; güvenin/inancın artması/ikna olma (7 öğretmen adayı), gurur duyma (1 öğretmen adayı), değer kazanma/takdir etme (3 öğretmen adayı), merakın/araştırma isteğinin artması (4 öğretmen adayı), gerekli değerin verilmemesi/ katkıların bilinmemesinden dolayı üzülme (2 öğretmen adayı) başlıkları altında toplanmıştır.

Güvenin/inancın artması/ikna olma ile ilgili olarak 14 numaralı öğretmen adayı, “Bilimin Doğası ve Tarihi dersinde gördüklerimizin üstüne bir de Türk-İslâm bilginlerinin buluşlarının ve icatlarının somut modellerini görmek beni bilime katkıları konusunda ikna etti." demiştir. 12 numaralı öğretmen adayı "Evet, olumlu yönde etkiledi. Anlatılanlar hikâye tadında oluyordu ama bütün bunları görmek daha ciddi bir inanç geliştirmeme sebep oldu. Türk-İslâm bilginleri çağlarının çok ilerisinde çalışmalar yapmışlar ve bizler de bunları görme firsatı bulduk." demiștir. 22 numaralı öğretmen adayı ise "Evet kesinlikle. $O$ kadar mükemmel ve komplike icatların olması, o dönemlerde bilimin ne denli geliştiğini gösterdi bana. İslâm bilginlerine olan güvenim daha 
da arttı." ifadesini kullanmıştır.

Gurur duyduğunu belirten 18 numaralı öğretmen adayı "Çok detaylı ve mükemmel teknolojik aletler vardı ve bu aletler kesinlikle benim atalarıma olan güvenirliğimi ve gururumu arttırdl." demiştir.

Değer kazanma/takdir etme ile ilgili olarak 1 numaralı öğretmen adayı, "Ben bu dersi alarak Türk-İslâm bilginlerine çok ilgi duydum, yaptığı çalışmaları çok takdir ettim. Müzeye gittikten sonra düşüncelerim daha da kuvvetlendi.” demiştir. 16 numaralı öğretmen adayı, “Kullanılan aletlere baktığımızda çoğu için nasıl düşünmüşler, bunu nasıl yapmışlar şeklinde beni hayretlere düşürdü ve bu aletlerle enteresan tespitlerde yapıyorlar. Oldukça etkileyiciydi. Türk-İslâm bilginleri gözümde daha da büyüdü. Kimisi çok estetik, kimisi çok yaratıcı, kimisi de yeni aletlere öncü olmuş.” demiştir.

Merakının/ araştırma isteğinin arttığını belirten 3 numaralı öğretmen adayı, "Öncelikle bilim tarihi dersimizde bilginlerin yaptıkları buluşları öğrenmek ve daha sonra yapmış olduğumuz gezi ile bu icatları görmek, Türk-İslâm bilginlerine daha çok merak duymamı sağladı ve bu zamana kadar neden bu bilginlerin bize bir nebze olsa da verilmemiş olması beni üzdü. Bugün gördüm ki, Türk-İslâm bilginleri bilime çok fazla katkıda bulunmuşlar.” demiştir. 6 numaralı öğretmen adayı, “Türk-İslâm bilim adamlarının bilime katkıları sandı̆̆ımdan da fazlaymış. Benim için çok ögretici oldu. Türk-İslâm bilim adamları hakkında daha çok bilgiye sahip olmak istiyorum. Bunun için de araştırmaya yöneleceğim. " demiştir. 
Gerekli değerin verilmemesinden/katkıların bilinmemesinden dolayı üzülme ile ilgili olarak ise 15 numaralı öğretmen adayı, “Evet, hem de olumlu bir şekilde. O zamanki insanların estetik duyguları çok gelişmiş. Bilimin temelini attılar diyemesek de çok iyi yerlere getirmişler. Bunların bilinmemesi beni çok üzüyor." demiştir.

Bilişsel alanla ilgili temada kodlamalar, soyut olan bilgilerin somutlaşması (4), farkındalığın artması (8) olmak üzere iki başlık altında toplanmıştır.

Soyut olan bilgilerin somutlaşması ile ilgili olarak 13 numaralı öğretmen adayı.” Etkiledi. Çünkü soyut olan şeyleri somut bir şekilde gördük. O kadar mekanizmayı düşünmeleri ve ince ayrıntıları düşünmeleri etkiledi." demiştir. 7 numaralı öğretmen adayı ise "Derste öğrendiklerimi destekledi. Buluşları vs. derste anlatıldı̆̆ında soyut geliyordu, şimdi daha da somutlaştı. Türk-İslâm bilim adamlarını daha iyi anlamama yardımcı oldu." demiştir.

Farkındalığın artması ile ilgili olarak 6 numaralı öğretmen adayı, "Türk İslâm bilim adamlarının bilime katkıları sandı̆̆ımdan da fazlaymış... Benim için çok ögrretici oldu.” demiştir. 24 numaralı öğrenci ise “Íslâm bilginlerinin o zamanda o kadar ince düşündüklerini hiç düşünmemiştim. Çünkü bizlere okullarımızda hep yabancı düşünürlerin bilime katkıları anlatılmıştı. Ancak gördüklerimden sonra Türk-İslâm bilginlerinin de bilime o kadar çok katkı sağladıklarını gördüm." demiştir. 


\section{c) Müze ziyareti öğrencilerin Türk-İslâm bilginleri ile ilgili}

\section{düşüncelerini nasıl etkilemiştir?}

Bu soruya, bütün öğretmen adayları müzede gördüklerinin onları çok etkilediği şeklinde cevap vermişlerdir. Öğretmen adaylarının cevapları incelendiğinde, ifadeleri duyuşsal alana ilişkin ve bilişsel alana ilişkin olmak üzere iki tema altında toplamanın mümkün olduğu görülmüştür. Duyuşsal alana ilişkin olarak öğretmen adayları, hayran kalma (5 öğretmen adayı), hayret etme/şaşırma (11 öğretmen adayı), beğenme (14 öğretmen adayı) ve gurur duyma (2 öğretmen adayı) şeklinde ifadelerde bulunmuşlardır.

Hayran kalma ile ilgili olarak 5 numaralı öğretmen adayı "Beni çok etkiledi. Çünkü dersimizde tanıdı̆̆ımız Türk-İslâm bilginlerinin geliştirmiş olduğu aletlere hayran kaldım. O zamanda bu kadar geniş düşünebilmeleri ve böyle aletleri hazırlayabilmeleri çok dikkat çekiciydi. Özellikle astronomi alanında geliştirilen usturlaplar vb. aletler çok güzeldi. Hem görsellik hem de eğiticilik vardı. Tıp alanındaki aletlerde çok güzeldi. O devirde yapılan aletlerin örneklerini, kitaplardan yararlanarak tekrar yapmışlar. Günümüzde kullandığımız aletlere temel oluşturuyor." demiştir. 10 numaralı öğretmen adayı ise “beni olumlu yönde etkiledi. Türk-İslâm bilginlerinin yaptı̆̆ı çalışmaları, çalışmalarda kullandıkları aletleri gördükten sonra daha çok hayranlık uyandırdı benim için. O dönemlerde çok fazla teknolojinin gelişmiş olmamasına ră̆men icat ettikleri aletleri o dönemdeki deneylerinde kullanmışlardır." demiştir.

Hayret etme/ şaşırma ile ilgili olarak 4 numaralı öğretmen adayı 
“dersimizde görmüştük ama insan görünce daha çok şaşırıyor. Nasıl yapılmış, nasıl düşünülmüş aa... bu nasıl olmuş falan gibi hayretle bakıyorsun." demiştir. 23 numaralı öğretmen adayı ise "Derste işlediklerimize göre birçok alet görmeyi bekliyordum ama beklediğimden daha çok alet gördüm ve bunlar oldukça gelişmiş aletlermiş. O zamanda böyle aletlerin yapılabilmesi beni hayretler içinde bıraktı." demiştir.

Beğendiğini ifade eden 9 numaralı öğretmen adayı, "Müzede gördüklerimden çok etkilendim. Müzede birçok bilim adamının yaptı̆̆ aletler ve eserler vardl. Müzeyi büyük bir zevkle gezdim. Aletleri incelerken kendime hep nasıl düşünmüşler sorusunu sordum. Eserlerine baktığımda onların çok geniş hayal güçlerinin ve muhakeme yeteneklerinin olduğu kanısına vardım. Saatler beni çok etkiledi. Eserlerde o zamanda bile estetiğe önem verildiğini gördüm. Türk-İslâm bilginlerinin bilime çok önemli katkılar yaptığını gördüm. Müzeye iyi ki gitmişim diyorum.” demiştir. 8 numaralı öğrenci ise "Çok beğendim. O zamanın şartlarında böyle icatların olması beni çok etkiledi. Yapmış oldukları saatler, saatlerin işleyişi beni çok büyüledi. Tip alanındaki aletler ilgimi çekti. Türk-İslâm bilginlerine merakım daha da arttı." demiştir.

Gurur duyduğunu belirten 12 numaralı öğretmen adayı. "Müzede gördüklerim oldukça etkiliydi. Atalarımızın neler yaptığını görmek çok duygulandırdı beni. O zamanın bilgileri ile, teknolojisi ile bu kadar ciddi çalışmaların yapılmış olması çok güzel. Ders kapsamında slaytlarda gördüğ̈̈müz ya da bahsedip geçtiğimiz usturlapları, fil saatini görmek çok etkileyiciydi.” derken, 19 numaralı öğretmen adayı “Mü- 
zede gördüklerim beni çok gururlandırdı ve çok şaşırttı. Türk-İslâm bilginlerinin çok fazla bilgiye sahip olduğunu ve bu bilgiler ışığında çeşitli aletler yaptıklarını gördüm. O zamanın teknolojisi ile bu aletleri yapabilmeleri beni çok şaşırttı, bu müze ziyareti sayesinde Türk-İslâm bilginlerinin bilime katkılarını gözlemlemiş oldum.” demiştir.

Bilişsel alana ilişkin ifadede bulunan öğretmen adayları; bilgilerinin daha kalıcı olduğunu (2 öğretmen adayı), düşüncelerinin değiştiğini/katkıyı daha iyi anladıklarını (1 öğretmen adayı), öğrendiklerinin daha anlamlı hale geldiğini (1 öğretmen adayı) ve kesinlik kazandığını (1 öğretmen adayı) ifade etmişlerdir.

Bilgilerinin daha kalıcı hale geldiğini belirten 4 numaralı öğretmen aday1, "En çok astronomi ve tıp bölümündeki icatlar daha çok ilgimi çekti, etkiledi. Böyle görmek de kalıcı olmasını să̆ladı.” demiştir.

Türk-İslâm bilginlerinin katkılarıyla ilgili düşüncelerinin değiştiğini/katkılarını anladığını ifade eden 20 numaralı öğretmen adayı, "Türklerin daha kuramsal boyutta çalışmalar yürüttükleri düşüncem değişti." demiştir.

Öğrendiklerinin daha anlamlı hale geldiğini ifade eden 16 numaralı öğretmen adayı, "Benim için bilgilerim daha kalıcı oldu. Olayları somutlaştırmak, bilgilerime daha da anlam kattı.” demiştir.

Bilgilerinin kesinlik kazandığını ifade eden 11 numaralı öğretmen aday1, "Türk-İslâm bilim insanlarının bilimde çok önemli yeri 
olduğunu gördüm. Birçok katkıları olduğu artık kesinlik kazanmış oldu." demiştir.

\section{d) Müze ziyareti öncesi, öğrencilerin Türk-İslâm bilginlerinin}

\section{katkılarıyla ilgili gerçeklik algıları nasıldır?}

Geziye katılan öğretmen adaylarının bu soruya verdikleri cevaplar üç farklı tema altında toplanmıştır. "Gerçeklik duygusu yaşama" (14 öğretmen adayı) "tam anlamıyla gerçeklik duygusu yaşamama” (2 öğretmen adayı) ve "gerçeklik duygusu yaşamama" (2 öğretmen aday1).

“Gerçeklik duygusu yaşama” ile ilgili olarak 6 numaralı öğretmen adayı, "Tabii ki yaşıyorum. Her ne kadar günümüz çağında Batılı bilim adamlarından konuşulsa, Türk-İslâm bilginlerinin adı lanse edilmese de bilimin gelişmesinde ve bilim tarihinde yadsınamayacak derecede katkıları vardır." 10 numaralı öğretmen adayı, "Batılı bilim insanları Íslâm bilginlerine göre daha çok tanınıyor ve biliniyor. Dolayısıyla onlar daha geçerli düşünülüyor. Bence Türk-İslâm bilginlerinin de bilime yaptığı katkılar düşünülürse onların da birçok çalışması (tıp fizik, biyoloji gibi) bilim dallarına temel oluşmuştur. Bu nedenle ben kendi adıma gerçeklik duygusu taşıyorum." demiştir.

"Tam anlamıyla gerçeklik duygusu yaşamama" ilgili olarak 1 numaralı öğretmen adayı, "Şu an bizim bilimimiz Batı bilimine odaklandı̆̆ı için Batı bilimini modern, gerçek ve kuramsal görüyoruz. Bize hep öyle gösterdiler. Bunun için tam manasıyla gerçeklik duygusu yaşayamıyorum. Fakat bulduklarını ve yaptıklarını öğrenmek beni 
heyecanlandırıyor.” demiştir. 21 numaralı öğretmen adayı, "Açıkçası bilimsel çalışmalarımıza rağmen bilincimin bir kenarında sanki hep bilim adına somut noktaları Avrupalılar bulmuş gibi gelmiştir. Bu yüzden bu nokta adına tam olarak fikrim değişti diyemem. Ama burada geçmiş bilgilerimizin de etkisi vardır. ” demiştir.

“Gerçeklik duygusu yaşamama” ile ilgili olarak 2 numaralı öğretmen adayı, "Türk İslâm bilginlerinin de bilime önemli katkılarl olduğunu biliyorum. Fakat bu Batılı bilim insanlarınınki gibi bir etki birakmiyor bende. Bunun sebebi de bence bu konuda yeterince bilgilendirilmemizden kaynaklanıyor.” demiştir. 7 numaralı öğretmen aday1: “Aslında yaşamıyorum çünkü öğrenim hayatım boyunca bilimi batılı bilim insanlarının yaptı̆̆ işler olarak algıladım. Bugüne kadar derslerimizde ögrrendiğimiz bilgiler daha çok Türk-İslâm bilginlerinin eseriymiş (örneğin trigonometri). Bize ĕger bunlar öğrenim hayatımız boyunca öğretilseydi onların katkıları için de gerçeklik duygusu algllayabilirdim. Her ne kadar derste Türk-İslâm bilginlerine daha çok önem versek de aynı gerçeklik duygusunu yaşayamıyorum." demiştir.

$\mathrm{Bu}$ soruya verilen cevaplardan ayrıca Bilimin Doğası ve Bilim Tarihi dersinin etkisine değinen ve ders sayesinde gerçeklik duygularında değişimler olduğunu belirten öğretmen adayları da vardır. Örneğin, 15 numaralı öğretmen adayı: “Bilimin Doğası ve Bilim Tarihi dersini alana kadar yaşamıyordum. Bu da onların hakkındaki bilgisizliğimden kaynaklanıyordu. Çeşitli kaynaklardan bilgi sahibi olunca gerçekliğine inandım. ” demiştir. 19 numaralı öğretmen adayı, "Bilimin Doğası ve Bilim Tarihi dersini almadan önce Batılı bilim insanlarının 
bilime katkılarının çok fazla olduğunu Doğu'daki toplumların katkılarının ise az olduğunu düşünüyordum. Bu yüzden Türk İslâm bilginlerinin katkılarını gerçek bulmuyordum." demiştir.

\section{e) Müze ziyareti, öğrencilerin Türk-İslâm bilginlerinin katkl-}

\section{ları ile ilgili gerçeklik algısını nasıl etkilemiştir?}

Öğretmen adayları bu soruya iki şekilde cevap vermişlerdir. Öğretmen adaylarının bir kısmı gerçeklik algısında fark yarattığını öğretmen adayı) söylerken, bir kısmı ise zaten böyle bir algıları olduğu için fark yaratmadığını (4 öğretmen adayı) söylemişlerdir.

Müze ziyaretinin algılarında fark yarattığını ifade eden öğrencilerden 4 numaralı öğretmen adayı "Görmeden önce nasıl olabilir falan gibi bir düşünce vardl, fakat görünce gerçekten ne güzel katkllarda bulunulmuş bunu gördüm. Evet böylece fark yarattı. Görünce hayretler içerisinde neler icat edilmiş dedim. Muhteşemdi." demiştir. 7 numaralı öğretmen adayı, "Evet yarattı. Katkılarını birebir (orijinal kopyalarını) görmek gerçeklik algımı biraz daha arttırdı." demiştir. 9 numaralı öğretmen adayı, "Türk-İslâm bilginlerinin yaptıkları araç-gereçleri yakından görünce gerçeklik algım daha da arttı. Türk-İslâm bilginlerimizin yaptıkları katkıları ögrenmiştim, fakat bu müzede gördükten sonra taşlar yerine çok daha iyi oturdu. Herkesin bu müzeyi gezmesi gerektiğini düşünüyorum.” demiştir. 12 numaralı öğretmen adayı.” Evet yarattı. Bu araç gereçleri görmüş olmak hem araç gereçlerin gerçekliğine olan şüphelerimi, hem de o zamanda onların yapılamayacağına olan düşüncelerimi yok etti. Türk-İslâm bilginlerinin katkllarının ne kadar ciddî olduğunu anlamış oldum" demiştir. 15 numaralı 
öğretmen adayı ise "Aslında Türk-İslâm bilginlerinin katkıları anlatıldiğında bunları boş bir övünme zannederdim. Lisede bazen ögretmenlerimin anlattı̆̆ şeyleri ise kendine mâl etme çabaları olarak algılardım. Bilimin Doğası ve Bilim Tarihi dersinde başlayan gerçeklik algım şu anda ilerledi ve onlara Batı bilim insanlarından daha çok saygı duymamı săgladı." demiştir.

Türk-İslâm bilginlerinin katkıları ile ilgili olarak zaten daha önce gerçeklik algılarının var olduğunu ve bu yüzden müze ziyaretinin algılarında bir fark yaratmadığı belirten öğretmen adaylarından $8 \mathrm{nu}$ maralı öğretmen adayı, "Bir fark yaratmadı. Gerçeklik duygusu yaşıyordum. Sadece kullanmış oldukları araç gereçler soyut olarak aklımdayken artık somutlaştı ve aklımda daha da kalıcı oldu." demiştir. 11 numaralı öğretmen adayı ise "Derslerde gördüğümde bilginlerin çalışmalarına zaten inanmıştım. Müzede gördüklerim kesinleştirdi”, demiştir.

\section{Tartışma}

Bilim tarihi ile ilgili anlatımlarda çoğunlukla hâkim olan anlayış, bilimin Rönesans'la birlikte atılım yaptığı ve bunun kökenlerinin de Yunanlılara dayandığı şeklindedir (Hobson, 2008). Buna göre bilim, Batı dünyası için "karanlık çağ" olarak nitelendirilen Ortaçağ'da duraklamış, 1500'lü yıllardan sonra da tekrar canlanmıştır. Tek yönlü olan bu bilim anlayışı, sadece Avrupa coğrafyası ile sınırlı kalmamış, Avrupa'nın endüstri devrimiyle birlikte ortaya çıkan teknolojik üstünlüğünün bir sonucu da olarak diğer coğrafyalarda, hatta İslâm dünyasında bile benzer şekilde etkisini göstermiştir (Sezgin, 2007). Bu bakış 
açısının etkisiyle, derslerde ve anlatımlarda çoğunlukla Batılı bilim insanlarının katkılarına yer verilmiş, keşif ve icatlar modern bilim çerçevesinde sunulmuştur. Dolayısıyla, öğrenciler sadece Batılı bilim insanlarının katkılarından haberdar olmuşlardır. Öğrencilerin bildikleri bilim insanları ile ilgili yapılan çalışmalarda çoğunlukla bu isimlere yer verdikleri tespit edilmiştir (Demirbaş, 2009; Korkmaz ve Kavak, 2010; Laçin Şimşek, 2011; Laçin Şimşek ve Şimşek, 2010; Oğuz Ünver, 2010; Song \& Kim, 1999). Oysa ki, insanlığın maddi ve manevi ürünlerini doğru biçimde değerlendirmek ve evrensel boyutta bir toplumun entelektüel kültür açısından yerini ve değerini nesnel olarak ortaya koyabilmek (Topdemir \& Unat, 2008) için bütün uygarlıklara ve kültürlere yer vermek gereklidir. Bu doğrultuda, Fen Bilgisi Öğretmenliği 3. sınıf Bilimin Doğası ve Bilim Tarihi dersinde, bilim tarihi ile ilgili anlatımlarda birçok farklı uygarlığın katkılarına yer verilmiştir. Türk-İslâm bilginlerinin katkıları anlatıldıktan sonra ise, öğrencilerin bu katkılarla ilgili düşünceleri ve bu katkıları somut olarak görebilecekleri bir müze ziyaretinin düşüncelerini nasıl değiştireceği tespit edilmek istenmiştir.

Bilimin Doğası ve Bilim Tarihi dersinde, Türk-İslâm bilginleri tanıtıldıktan sonra yapılan müze ziyareti öncesinde öğretmen adaylarına Türk-İslâm bilginlerinin katkılarıyla ilgili ne düşündükleri sorulmuştur. Öğretmen adaylarının hepsi önemli katkıları olduğunu düşündüklerini belirtmişlerdir. Ancak burada, öğretmen adaylarının bu bilginlerin katkılarını derste öğrenmiş olduklarını göz önünde bulundurmak gereklidir. Bazı öğretmen adayları dersten önce bu isimleri duy- 
mamış olduklarından ve dersin etkisinden bahsetmişler hatta bazıları da bu derse kadar bu bilginlerden haberdar olmamaları konusunda serzenişte bulunmuşlardır. Bu durum, eğitim sistemimizde var olan Batılı bilim anlayışının (Göker, 1998; Sezgin, 2007) bir sonucu olarak karşımıza çıkmaktadır.

Müze ziyareti sonrasında, öğretmen adaylarına müzede gördüklerinin Türk-İslâm bilginlerinin bilime katkıları ile ilgili düşüncelerini nasıl etkilediği sorulmuştur. Bu soruya öğretmen adayları bilişsel ve duyuşsal alana yönelik ifadelerde bulunarak cevap vermişlerdir. $\mathrm{Bu}$ ziyaretin, anlatıldığında soyut gelen bilgilerin somutlaşmasını sağladığını belirten öğretmen adayları olduğu gibi, katkıların farkına daha çok vardıklarını belirten öğretmen adayları da bulunmaktadır. Bu durum, müze ziyaretinin görsel ve üç boyutlu gerçek unsurlar sunarak, öğretmen adaylarının zihinlerinde tam olarak oturmamış birtakım düşünce ve kavramların daha iyi anlaşılmasını sağladığı şeklinde yorumlanabilir. Ayrıca, müze ziyareti öncesinde Türk-İslâm bilginleri ile ilgili bilgiler sunulmuş olmasının da müze ziyaretinin verimliliğini arttırdığı söylenebilir. Yapılan çalışmalarda, müze ziyareti öncesinde verilen eğitimin ve ön bilgilerin varlığının ziyaret esnasındaki bilgi kazanımını arttırdığı tespit edilmiştir (Hannu, 1993; Falk ve Adelman, 2003; Ramey-Gassert, 1997). Ziyaret ile birlikte, Türk-İslâm bilginlerinin katkılarının gerçekliğine olan inancın arttığını, katkılarına ikna olduklarını, gurur duyduklarını, bilginlerin daha çok değer kazandığını belirten öğretmen adayları da vardır. Bunun yanında bilginlere yönelik meraklarının ve araştırma yapma isteklerinin arttığını belirten öğretmen 
adayları da bulunmaktadır. Schauble ve diğ., 1996 (akt., Griffin, 2004), Rennie (1994) ve DeWitt ve Osborne (2007)'da müze ziyaretlerinin motivasyon ve ilgiyi artırdığını belirtmektedirler. Diğer yandan, bilginlere gerekli değerin verilmemesinden, katkıların bilinmemesinden dolayı üzgün olduklarını belirten öğretmen adayları da bulunmaktadır. Burada verilen ifadelerde, dersteki anlatımlarla verilmiş bilgilerin öğrencilerde bir fikir oluşturduğu ancak bilhassa müze ziyareti sonrasında katkılarla ilgili ciddî bir farkındalık oluştuğu görülmektedir. Ayrıca, öğretmen adaylarının kendi kültürlerine ait unsurlarla karşılaşmış olmalarının da bu düşüncelerin oluşmasında etkili olduğu söylenebilir. Yapılan başka çalışmalarda da, buna paralel biçimde ziyaretlerde kendi kültürleriyle ilgili unsurların bulunmasının öğrencilerde daha fazla etki yaptığ1 tespit edilmiştir (Anderson ve diğ., 2002). Bunu, öğretmen adaylarının ifadelerinde yer alan "Gurur duydum, hayran oldum, etkilendim" ifadeleri ile desteklemek mümkündür. Öğretmen adaylarının ziyaret öncesi Türk-İslâm bilginlerinin katkıları sorulduğunda, önemli katkılar yaptıklarını bildiklerini belirtmekle yetindiklerini ancak ziyaret sonrasında bu katkılara inancın ve güvenin artmasıyla, bilginleri daha da içselleştirdiklerini söylemek mümkündür.

Müze ziyareti öncesinde öğretmen adaylarının çoğu bu katkılarla ilgili gerçeklik algısı yaşadıklarını ifade etmişlerdir. Ancak bir kısmı, gerçeklik algılarının tam olmadığını ya da Batılı bilim insanlarının yaptıkları katkıların daha gerçekçi geldiğini belirtmişlerdir. Burada da, eğitim sistemimizde var olan batılı bilim tarihi anlayışının etkilerinden söz etmek mümkündür. Yıllarca sadece Batılı bilim insanlarının isim- 
lerini, keşiflerini duymuş olan öğretmen adayları, derste gördükleri diğer uygarlıklara ilişkin katkılarla ilgili olarak gerçeklik duygusunu aynı yoğunlukta yaşamamaktadırlar. Ancak, bu durumun az sayıda öğretmen adayı tarafindan dile getirilmiş olması olumlu bulunmuştur. Müze ziyaretinin öğretmen adaylarının Türk-İslâm bilginlerinin katkıları ile ilgili gerçeklik algılarında fark yaratıp yaratmadığı sorulduğunda, öğretmen adaylarının büyük çoğunluğu fark yarattığını söylemişlerdir. Bir kısmı ise, zaten gerçeklik algısı taşıdıkları için fark yaratmadığını belirtmişlerdir. Bu noktada, müze ziyaretinin algıları etkilemesi, değiştirmesi yönünde olumlu katkılarının olduğunu söylemek mümkündür.

Müze ziyaretinin öğretmen adaylarını nasıl etkilediğinin sorulduğu soruda ise, öğretmen adaylarının olumlu görüşler belirttikleri görülmüştür. Öğretmen adayları, müzede gördüklerinin kendilerini hayran bıraktığını, gördükleri karşısında hayret ettiklerini, şaşırdıklarını, beğendiklerini, gördükleriyle gurur duyduklarını belirtmişlerdir. Ayrıca, ziyaretlerinin öğrendikleri bilgilerin kalıcı olmasını sağladığını, düşüncelerinin değiştiğini ve katkıları anladıklarını, öğrendikleri bilgilerin daha anlamlı hale geldiğini ve kesinlik kazandığını belirtmişlerdir. Görüldüğü gibi, müze ziyareti öğretmen adaylarında hem duyuşsal hem de bilişsel alanda farklılıklar yaratmıştır. Bu durum, daha önceki çalışmalarda elde edilen müze ziyaretinin hem bilişsel hem de duyuşsal alana yönelik olarak katkı yaptığg bulgularını desteklemektedir (Anderson ve diğg., 2006).

Çalışmaya katılan öğretmen adaylarının hepsi müzeden çok et- 
kilendiklerini, müzeyi çok beğendiklerini ifade etmişlerdir. Ancak, bunun yanında, müze ile ilgili birtakım eleştiriler sunan öğretmen adayları da olmuştur. Bu eleştirileri, müzede bulunan aletlerin açıklamalarının, nasıl çalıştıkları ile ilgili bilgilerin bulunmaması, etiketlerin yeterli olmaması şeklinde gruplandırmak mümkündür. Örneğin, 2 numaralı öğretmen adayı, "Müzede yer alan aletlerin ne amaçla kullanıldiğı da belirtilmiş olsaydı daha etkili olur diye düşünüyorum.” demiştir. 3 numaralı öğretmen adayı, "Bir de aletleri çalışır halde görsem benim üzerimdeki etkileri bir kat daha artabilirdi.” ve 18 numaralı öğretmen aday1: "Müze çok güzel ve aydınlatıcı yapıdaydı. Fakat aletlerin kullanım amaçlarından daha fazla bahsedilmeliydi." şeklinde görüş belirtmişlerdir. Falk (1997) yaptığı bir çalışmada öğrencilerin sunulan sergilerde etiketlerin olduğu ve olmadığı iki müze gezisi neticesinde etiketlerin var olduğu müzede daha fazla zaman harcadıkları ve müze gezisi sonrasında yapılan testte daha yüksek puan almaları sonucuna dayanarak etiketlerin öğrenmeyi arttırdığını ifade etmiştir. Benzer şekilde bu çalışmada da öğretmen adaylarının sergilenen materyallere ilişkin etiketlerin olmayışını, olumsuz bir eleştiri olarak ortaya koydukları ve eğer olsaydı müze ziyaretinin daha etkili olacağını ifade ettikleri görülmektedir.

\section{Sonuç}

$\mathrm{Bu}$ çalışmada, müze ziyaretinin öğretmen adaylarının algıları üzerindeki etkisi incelenmiştir. Bilimin Doğası ve Bilim Tarihi dersinde Türk-İslâm Bilginlerinin katkıları anlatıldıktan sonra yapılan müze ziyareti sonrasında, öğretmen adayları, bu ziyaret ile öğrendikleri 
bilgilerin pekiştiğini, daha anlamlı geldiğini, bilginlerin kullandıkları araç-gereçleri somut olarak görmenin onları bu katkılar konusunda ikna ettiğini belirtmişlerdir. Müzeye yapılan ziyaret sayesinde, derste isimlerini yeni öğrenmiş oldukları birçok Türk-İslâm bilgininin artık daha gerçekçi geldiğini ve onlarla gurur duyduklarını belirten öğretmen adayları da olmuştur. Yıllarca Batılı bilim insanlarının katkılarını öğrendiklerini belirterek, Türk-İslâm bilginlerinin katkılarının Batılı bilim insanlarınınki gibi gerçekçi gelmediğini söyleyen öğretmen adayları dahi, bu ziyaret sonrasında bilginlerin katkıları konusunda ikna olduklarını ve gerçeklik algılarının arttığını ifade etmişlerdir. Elde edilen bu bulgular doğrultusunda, müze ziyaretlerinin, öğrenilen bilgilerin pekişmesini ve daha anlamlı hâle gelmesini sağladığını, düşüncelerinin değişmesinde olumlu etkileri olduğunu söylemek mümkündür. Ayrıca, ziyaretin duyuşsal alana yönelik birtakım farklılıklar da yarattığı, öğretmen adaylarının "gurur duyma, hayran kalma, beğenme" gibi duygulardan bahsettikleri görülmüştür. $\mathrm{Bu}$ durum da öğrenmenin daha anlamlı hâle geldiğinin bir başka göstergesi olarak değerlendirilebilir. Böylelikle müzelerin etkili öğrenme ortamları oldukları ve derslerde sıklıkla yer verilmesinin öğrenme üzerinde olumlu katkılar yapacağı sonucuna ulaşılabilir. Bu noktada dersler anlatılırken uygun konular için müzelere gezi düzenlenmesi önerilebilir.

\section{Kaynakça}

Anderson, D., Kisiel, J. ve Storksdieck, M. (2006). Understanding teachers' perspectives on field trips: Discovering common ground in three countries. Curator, 49(3), 364-386. 
Anderson, D., Lucas, K. B., Ginns, I. S. ve Dierking, L. D. (2000). Development of knowledge about electricity and magnetism during a visit to a science museum and related post-visit activities. Science Education, 84(5), 658-679.

Anderson, D., Piscitelli, B.Weier, K., Everett, M. ve Tayler, C. (2002). Children's museum experiences: Identifying powerful mediators of learning. Curator, 45(3), 213-231.

Balkan Kıyıc1, F. ve Atabek Yiğit, E. (2010). Science education beyond the classroom: a field trip to wind power plant. International Online Journal of Educational Sciences, 2(1), 225-243.

Baykan, Z. Ö. (2007). 2005 ve 2006 ilköğretim programlarının müze eğitimi açısından değerlendirilmesi. Yayımlanmamış Yüksek Lisans Tezi, Ankara Üniversitesi Sosyal Bilimler Enstitüsü.

Bozdoğan, A. E. (2007). Bilim ve teknoloji müzelerinin fen eğitimindeki yeri ve önemi. Yayımlanmamış doktora tezi, Gazi Üniversitesi Eğitim Bilimleri Enstitüsü.

Büyüköztürk, Ş., Kılıç Çakmak, E., Akgün, Ö. E., Karadeniz, Ş. ve Demirel, F. (2008). Bilimsel araştırma yöntemleri. Ankara: PegemA Yayıncılık.

Chin, C-C. (2004). Museum experience-a resource for science teacher education. International Journal of Science and Mathematics Education, 2(1), 63-90. 
Cox-Petersen, A. M. (1999). Dive into research at the aquarium. Science Activities, 36(3), 34-36.

Demirbaş, M. (2009). Türkiye’deki bilim ve sanat merkezlerinde öğrenim gören üstün yetenekli öğrencilerin bilim adamı imgeleri. Journal of Qafqaz University, 28, 197-207.

DeWitt, J. ve Osborne, J. (2007). Supporting teachers on science focused school trips: towards an integrated framework of theory and practice. International Journal of Science Education, 29(6), $685-710$.

Dori, Y. J. ve Tal, R. T. (2000). Formal and informal collaborative projects: engaging in industry with environmental awareness. Science Education, 84(1), 95-113.

Falk, J. ve Storksdieck, M. (2005). Using the contextual model of learning to understand visitorlearning from a science center exhibition. Science Education, 89(5), 744-778.

Falk, J. H ve Dierking, L. D. (2002). Lessons without limit: How free choice learning is transforming education. Walnut Creek: Altamira Press.

Falk, J. H. (1997). Testing a museum exhibition design assumption: effect of explicit labeling of exhibit clusters on visitor concept development. Science Education, 81(6), 679-687.

Falk, J. H. ve Dierking, L. D. (1997). School field trips: assessing their 
long-term impact. Curator, 40(3), 211-218.

Falk, J. H. ve Adelman, L. M. (2003). Investigating the impact of prior knowledge and interest on aquarium visitor learning. Journal of Research in Science Teaching, 40(2), 163-176.

Göker, L. (1998). Fen bilimleri tarihi ve Türk islam bilginlerinin yeri. Ankara: MEB Yayınları.

Griffin, J. (2004). Research on students and museums: looking more closely at the students in school groups. Science Education, 88(1), 59-70.

Guisasola, J., Morentin, M. ve Zuza, K. (2005) School visits to sciencemuseums and learning sciences: a complex relationship. Physics Education, 40(6), 544-549.

Hannu, S. (1993). Science centre education. motivation and learning in informal education. research report 119. Yayınlanmamış doktora tezi, Helsinki University Department of Teacher Education.

Hobson, J. M. (2008). Batı medeniyetinin doğulu kökenleri. İstanbul: Yap1 Kredi Yayınları.

Korkmaz, H. ve Kavak, G. (2010). İlköğretim öğrencilerinin bilime ve bilim insanına yönelik imajları. Illköğretim Online, 9(3), 1055-1079.

Laçin Şimşek, C. (2011). Bilimin doğası ve bilim tarihi dersinde yapı- 
lan çalışmaların öğrencilerin bilim tarihi ile ilgili bilgi düzeylerine etkisi. Necatibey Egitim Fakültesi Elektronik Fen ve Matematik Egitimi Dergisi (EFMED), 5(1), 116-138.

Laçin Şimşek, C. ve Şimşek, A. (2010). Türkiye'de bilim tarihi öğretimi ve sosyal bilgiler öğretmen adaylarının yeterlilikleri. Uluslararası Insan Bilimleri Dergisi, 7(2), 170-198.

Oğuz Ünver, A. (2010). Perceptions of scientists: a comparative study of fifth graders and fourth year student teachers. Necatibey Egitim Fakültesi Elektronik Fen ve Matematik Egitimi Dergisi (EFMED), 4(1), 11-28.

Panizzon, D. ve Gordon, M. (2003). Mission possible: a day of science, fun and collaboration. Australian Primary \& Junior Science Journal, 19(2), 9-14.

Ramey-Gassert, L. (1997). Learning science beyond the classroom. The Elementary School Journal, 97(4), 433-450.

Rennie, L. J., Feher, E., Dierking, L. D., ve Falk, J. H. (2003). Toward an agenda for advancing research on science learning in out-of-school settings. Journal of Research In Science Teaching, 40(2), 112-120.

Rennie, L. J. (1994). Measuring affective outcomes from a visit to a science education centre. Research in Science Education, 24(1), 261-269. 
Seidel, S. ve Hudson, K. (1999). Müze eğitimi ve kültürel kimlik. (B. Ata, Çev.). Ankara: Ankara Ünv. Sosyal Bilimler Ens. Yayınları.

Sezgin, F. (2007). İslam'da bilim ve teknik (Cilt 1). İstanbul: Kültür ve Turizm Bakanlığı Yayınları.

Song, J. ve Kim, K. (1999). How Korean students see scientists: the images of the scientist'. International Journal of Science Education, 21(9), 957-977.

Topdemir, H. G. ve Unat, Y. (2008). Bilim tarihi. Ankara: Pegem Akademi. 